\title{
Implications of Auction Theory for New Issues Markets
}

LAWRENCE M. AUSUBEL

I

MAGINE ATTEMPTING TO explain to a visitor, from another era or another planet, the economic rationale behind various institutions in the American economy at the start of the twenty-first century. Few practices seem more difficult to justify to the outsider than the current procedure for the issuance of equity securities. The share price in initial public offerings (IPOs) often bears little connection to the equating of supply and demand, so IPOs are sometimes massively oversubscribed and the share price increases by as much as a factor of five from the offering price to the close of the first day of trading. Shares in these oversubscribed offerings are rationed, not according to willingness to pay but to favored clients of the underwriting investment banks. Often there is at least the appearance that clients receive their allotments in exchange for returning value to the investment banks in other transactions; and recently there have been allegations that some allotments have been made in exchange for agreements to buy additional shares on the open market after the IPO. Although the associated returns forgone by the sellers (that is, the companies going public) would be easier to justify if the explicit fees for the service were

The author is grateful to collaborators and co-authors on the various projects and publications described in this paper, including Kathleen Ausubel, Peter Cramton, Ulrich Gall, Eric Maskin, Paul Milgrom, and Jesse Schwartz, and to Peter Grajzl for excellent research assistance. The generous support of National Science Foundation Grant SES-01-12906 is gratefully acknowledged. 
commensurately discounted, the explicit fees charged for IPOs seem quite high, generally a 7 percent commission on proceeds from the new shares. ${ }^{1}$

The main objective of this paper is not to hammer away at the inefficiencies present in the current system of new equity issuance or to explain what prevents the current system from being swept aside. Rather, this paper seeks to draw from new developments in market design-both theoretical results and new practices in other sectors-and to highlight alternative procedures that may be best suited to supplementing or replacing the current flawed system.

\section{Comments on Current Practice for New Equity Issuance}

The years 2000 and 2001 have seen Securities and Exchange Commission (SEC) investigations into two alleged abuses in the current practice for new equity issuance, a $\$ 100$ million tentative settlement of charges by Credit Suisse First Boston, and a plethora of private lawsuits. In May 2001, the Economist provided an early, well-written, and somewhat skeptical synopsis: ${ }^{2}$

Were investment banks crooked when they made billions of dollars from the Internet bubble?

It [Wall Street] enjoyed the dotcom party as much as anyone. But now that the whole thing has ended messily, Wall Street has become everybody's favourite scapegoat. Its analysts are accused of abandoning objectivity to tout shares that their investment banks underwrote. Underwriters are said to have set the share price too low in initial public offerings (IPOs), so as to ensure a huge jump in the price when trading began. That jump in turn enabled investment banks to reward favoured clients who were allocated shares in the IPO, which clients could instantly sell at a fat profit. To compound the rascality, the banks shared in those profits by demanding return favours from the clients.

No matter how far-fetched or corrupt this scenario seemed, by early 2002 substantial evidence had accumulated supporting some of these claims. Credit Suisse First Boston had reached final agreement on a $\$ 100$ million settlement of government charges. According to published

1. The underwriting commission was exactly 7 percent for more than 90 percent of U.S. IPOs raising $\$ 20$ million to $\$ 80$ million in recent years (Chen and Ritter 2000).

2. Economist (2001). 
accounts, "The regulators singled out First Boston, accusing it of demanding that customers pay back some of the profit they made from trading new stocks in the form of inflated commissions on other stock trades. Investigators gathered evidence, including e-mail messages, that indicated that the firm's sale representatives had told some customers to pay the firm at least $\$ 1$ in commissions for every $\$ 3$ of new-stock trading profits. ${ }^{, 3}$ Furthermore, "Plaintiffs' lawyers have filed more than 1,000 lawsuits against First Boston and about four dozen other securities firms, asserting that they manipulated the prices of new stocks in various ways. Those suits contend that sales representatives at First Boston gave relatively big allocations of new stocks to professional investors in exchange for a share of the profits those buyers made by reselling the stocks. They also contend that other investment banks, including Goldman Sachs and Morgan Stanley Dean Witter, solicited promises from investors that they would buy more shares of a new stock at higher prices after it started trading. Such arrangements, expressly prohibited by securities laws, could have driven new stocks to artificially high prices. Spokeswomen for Goldman Sachs and Morgan Stanley declined to comment. Federal regulators are continuing to investigate the second practice, known on Wall Street as 'laddering' a stock, and they may still bring charges against one or more investment banks."

There has been some speculation that the SEC and the National Association of Securities Dealers (NASD) might issue rules forbidding kickbacks or inflated commissions in IPO allocations. But, according to published accounts, regulators correctly recognize that an incremental change in rules may do little to prevent recurrent abuses. "It's very difficult to draw up rules to regulate allocation of shares that are underpriced," one official is quoted as saying. ${ }^{5}$

Rather, the perspective of this paper is that a more radical overhaul of current practice is necessary: a change to a modern auction system that provides an open, transparent mechanism for price discovery. This is the clearest way to eliminate the current underpricing - and the accompanying incentives for abuse.

3. McGeehan (2001, p. C1).

4. McGeehan (2001, p. C1).

5. Labate (2001, p. 23). 


\section{Auction Theory Preliminaries}

This section provides some background information on auction formats that might be contemplated for new issues markets and some associated results in the literature.

\section{Sealed-Bid, Multi-Unit Auction Formats}

Sealed-bid, multi-unit auction formats are best known in the financial sector for their longtime and widespread use in the sale of central government securities. For example, ten years ago, the Joint Report on the Government Securities Market surveyed Organization for Economic Cooperation and Development (OECD) countries and found that the United States, Australia, Canada, Denmark, France, Germany, Italy, Japan, New Zealand, and the United Kingdom were using sealed-bid auctions for selling at least some of their government securities. ${ }^{6}$ For many years, sealed-bid auctions have also been used rather extensively for share repurchases by publicly traded companies and, in relatively rare instances, for IPOs. ${ }^{7}$

PAY-AS-BID AUCTIONS. In pay-as-bid auctions,${ }^{8}$ bidders submit sealed bids that effectively comprise demand curves. The auctioneer aggregates the bids and determines the clearing price at which demand equals supply. Each bidder wins the quantity demanded at the clearing price and pays the amount that he bid for each unit won.

UNIFORM-PRICE AUCTIONS. In uniform-price auctions, ${ }^{9}$ bidders submit sealed bids that effectively comprise demand curves. The auctioneer aggregates the bids and determines the clearing price at which demand

6. U.S. Department of the Treasury, U.S. Securities and Exchange Commission, and Board of Governors of the Federal Reserve System (1992, pp. B-25-B-26).

7. On share repurchases, see Bagwell (1992); Gay, Kale, and Noe (1991). On IPOs, see Kandel, Sarig, and Wohl (1999); Sherman (2001).

8. Pay-as-bid auctions are often referred to as pay-your-bid auctions or, less descriptively, as discriminatory auctions or multiple-price auctions. They generalize the sealed-bid, first-price auction for single items.

9. Uniform-price auctions are often referred to in the financial press, less descriptively, as Dutch auctions and elsewhere as nondiscriminatory auctions, competitive auctions, or single-price auctions. It is sometimes asserted (incorrectly) that they generalize the sealedbid, second-price auction for single items. However, the correct multi-unit generalization of the second-price auction is due to Vickrey (1961). 
equals supply. Each bidder wins the quantity demanded at the clearing price and pays the clearing price for each unit won.

\section{Ascending-Bid, Multi-Unit Auction Formats}

Ascending-bid, multi-unit auction formats have become dominant in recent years for government sales of telecommunications spectrum. They are also coming into significant use in the energy and environmental sectors.

SIMULTANEOUS ASCENDING AUCTIONS. In simultaneous ascending auctions, the items are auctioned simultaneously in multiple rounds of bidding. ${ }^{10}$ In each round, bidders may submit new bids. A bid is a pair comprising an item and an associated price (higher than the standing high bid). Bids can continue to be submitted for any item until the auction ends for all items; the auction ends only when a round elapses with no new bids submitted for any of the items.

ASCENDING-CLOCK AUCTIONS. In ascending-clock auctions, in each round, the auctioneer announces a price (or price vector) for the items being auctioned, and bidders respond with bids. ${ }^{11} \mathrm{~A}$ bid comprises a quantity of items demanded at the announced price. If the aggregate demand exceeds the supply, the auctioneer raises the price and the process repeats. The auction ends at the first price at which aggregate demand is less than or equal to supply.

Variations on the simultaneous ascending auction were used during 1994-2001 for spectrum auctions on six continents generating more than $\$ 100$ billion in revenues. Among the best-known examples of these auctions were the U.S. PCS auctions of 1994-96 and 2001, the U.K. 3G auction in 2000, and the German $3 \mathrm{G}$ auction in 2000. When large numbers of identical items are to be auctioned — as is the case in the issuance of equity or debt securities - it is often advantageous to formulate the procedure as an ascending-clock auction. Since the auctioneer, rather than bidders, names the prices in a clock auction, the auctioneer has greater control over the speed of the clock auction and can ensure that it runs at a deliberate pace. The Electricité de France generation capacity auction and the U.K. emissions trading scheme auction, described in the next section, are two examples of high-stakes ascending-clock auctions.

10. See Cramton (1995); Milgrom (2000).

11. See Ausubel (1997, 1999, 2000a, 2000b). 


\section{Standard Results of Auction Theory}

Auction formats are generally evaluated according to two criteria: (a) efficiency, the extent to which the auction assigns items to the bidders who value them the most, and (b) revenue maximization, the extent to which the auction maximizes the seller's expected revenues. Most of the early results of auction theory concern sales of single items. If bidders are symmetric and have pure private values, the sealed-bid first-price, the sealed-bid second-price, and the ascending (English) auction all achieve equal efficiency and seller revenues. However, to the extent that bidders' valuations are affiliated (approximately meaning positively correlated) with one another, ascending auctions outperform sealed-bid auctions with respect to revenues. ${ }^{12}$ The intuition often provided for this result is that sealed-bid auctions are particularly susceptible to the winner's curse: a bidder is more likely to win an auction when opposing bidders possess unfavorable information and so, in this sense, winning may be bad news. However, since an ascending auction provides bidders with continuous feedback about the opposing bidders' valuations, providing opportunities to draw inferences and to respond accordingly, it ameliorates the winner's curse and leads, on average, to more aggressive bidding, which ultimately benefits the seller. ${ }^{13}$

Recent work in the auction literature has examined multi-unit auctions. Much of the empirical emphasis has been on the revenue comparison between pay-as-bid auctions and uniform-price auctions. Indeed, the U.S. Treasury conducted an "experiment" from 1992 to 1998 of using the uniform-price auction for selling two-year and five-year notes and using the pay-as-bid auction for selling other Treasury durations. ${ }^{14}$ It then switched entirely to the uniform-price auction in November 1998. However, the theoretical literature makes clear that, except in very special circumstances, the revenue rankings of the pay-as-bid and uniform-price auctions are inherently ambiguous, and both formats inevitably yield inefficient outcomes. ${ }^{15}$ Moreover, any focus on the pay-as-bid and uniform-price formats ignores other types of auctions that are likely to outperform both.

12. Milgrom and Weber (1982).

13. See McAfee and McMillan (1987) for an excellent survey of the early results of auction theory.

14. Malvey and Archibald (1998).

15. Ausubel and Cramton (1996). 
In particular, ascending-bid, multi-unit auction formats offer several decisive advantages over sealed-bid, multi-unit auction formats. First, the insight from single-item auctions that the continuous feedback about other bidders' valuations would ameliorate the winner's curse and lead to more aggressive bidding should be expected to carry over to many multi-unit environments. This intuition led the Joint Report on the Government Securities Market to conclude, "Irrespective of whether the single-price, sealedbid auction would prove superior to the current practice, the Agencies believe that there is an auction technique that may be superior to both types of sealed-bid auction techniques discussed above. This is an ascendingprice, open auction system, which will be feasible for the first time once the auctions are automated." ${ }^{16}$ Second, ascending-clock auctions, better than sealed-bid auctions, allow bidders to maintain the privacy of their valuations for the items being sold. Bidders never need to submit an indication of interest at any price above the auction's clearing price. Third, an efficient ascending-bid auction format, improving on the design of the basic clock auction, has been developed in recent years. This paper continues by, first, describing two practical implementations of clock auctions and then explaining the efficient ascending-bid auction.

\section{Case Studies: High-Stakes Auctions in Other Sectors of the Economy}

This section of the paper does not attempt to provide a comprehensive survey of modern auction techniques as applied to other sectors of the economy. Rather, it focuses on two specific high-stakes, real-world auctions using designs that are also well suited for financial services applications, including the issuance of securities. ${ }^{17}$

\section{The Electricité de France Generation Capacity Auctions}

Electricité de France (EDF), the dominant power producer in France and the world's largest electricity group, committed in an agreement with the European Commission (in connection with EDF's acquisition of a

16. U.S. Department of the Treasury, U.S. Securities and Exchange Commission, and Board of Governors of the Federal Reserve System (1992, pp. 14-15).

17. The author helped to run both projects. 
substantial interest in German utility Energie Baden-Württemberg AG) to begin the divestment of 6,000 megawatts of generation capacity in 2001 . The 6,000 megawatts to be sold represented approximately 10 percent of France's electricity supply. This divestment would be accomplished not by selling the physical power plants, but by selling virtual power plants (VPPs), option contracts replicating the output of the power plants. Two basic types of virtual power plants would be sold: (a) base-load VPPs, whose strike prices would equal the variable cost of a nuclear power plant (and so the options would be exercised essentially around the clock, 365 days per year), and (b) peak-load VPPs, whose strike prices would equal the variable cost of a peak-load plant (and so the options would be exercised only at peak times). Base-load and peak-load VPPs in a variety of durations would be offered. In addition, a third type of product-power purchase agreements (PPAs) — would be sold. PPAs represent a block of power based on the output from co-generation plants under power purchase contracts.

The French generation capacity is being sold by way of a dynamic, ascending-clock auction. To date, EDF has conducted three capacity auctions, in September 2001, December 2001, and March 2002, advised by PricewaterhouseCoopers and Market Design Incorporated. The following description focuses largely on the first auction, in which VPPs representing some $€ 300$ million worth of electricity were sold. ${ }^{18}$

In the first auction, an initial tranche of 1,190 megawatts of electricity was offered. This generation capacity was sold in fifteen products, ordered as five product groups:

-Product group A: VPP base-load product, with six durations, all beginning on January 1, 2002, in a supply of 800 megawatts,

-Product group B: VPP peak-load product, with six durations, all beginning on January 1, 2002, in a supply of 200 megawatts,

18. The author managed Market Design's participation in the project, which included designing the auction, developing the auction software, and advising EDF in the conduct of the auction. University of Maryland professor Peter Cramton also contributed to all aspects of Market Design's participation in the project. More detailed information about the EDF generation capacity auctions is available at www.efficientauctions.com/electricity.htm [May 31, 2002] and www.edf.fr/htm/en/enchere/enchere/ [May 31, 2002]. Further information about the auction software and its availability for applications in the financial services sector is available from the author. Further materials on auction theory and practice are available on the author's website, www.ausubel.com, and on www.market-design.com and www.efficientauctions.com. 
-Product group C: VPP base-load product, with one duration lasting from November 1, 2001, through December 31, 2001, in a supply of 800 megawatts, limited by group A,

-Product group D: VPP peak-load product, with one duration lasting from November 1, 2001, through December 31, 2001, in a supply of 200 megawatts, limited by group B,

-Product group E: PPA product, with one duration lasting from November 1, 2002, through December 31, 2002, in a supply of 190 megawatts.

In broad perspective, the auction is conducted as a practical implementation of the fictitious "Walrasian auctioneer" of microeconomics theory. The auctioneer (seller) begins the auction by announcing a price vector for each of the fifteen products. The participating bidders (buyers) each respond by demanding a quantity of each of the fifteen products (limited by a constraint that no single bidder can demand more than 45 percent of the available supply). The auctioneer announces the aggregate demand for each product, compares the aggregate demand for each product group with the available supply, and adjusts the price vector accordingly. The process is repeated until all of the product groups clear.

The EDF generation capacity auctions are implemented on proprietary, commercial-grade software designed for clock auctions. The auction software operates on a web server located in Europe, with a backup server located in the United States. Bidders submit bids in the auction and follow the auction's progress using standard web browsers (Internet Explorer or Netscape Navigator). The auction software uses a variety of security features, including 128-bit SSL encryption (the same standard used by financial institutions on the Internet), a digital certificate for authentication, a web server protected by a firewall, and login identities and passwords distributed to bidders by nonelectronic means. In the event that an individual bidder suffers failure of his own computer system or Internet connection, the bidder contacts the auction administrator and submits his bid by fax. The software then permits the auction administrator to enter a bid on behalf of a bidder. All transactions on the auction system are recorded in an audit file. The audit file notes the time and amount of all bid submissions. It also records such other events as a bid placed by the auction administrator on behalf of a bidder.

The three EDF generation capacity auctions to date appear to have been entirely successful. They attracted the participation of some forty-five energy traders and suppliers, with more than twenty bidders emerging as 
successful purchasers. The first two auctions concluded in ten rounds each, and the third auction concluded in nine rounds. Due to the fact that it was the first auction, the September auction was conducted on a relatively relaxed schedule and took two days. Beginning with the second auction, the bidding has concluded in a single day: the bidders were experienced, and after the second round, the auction could be conducted on a schedule of thirty-minute bidding rounds followed by thirty-minute breaks between rounds.

The parties involved consider the auction process to have achieved an extremely good result. The electricity generally traded at a premium relative to secondary-market prices in nearby countries. The auction software performed flawlessly. The simultaneous ascending-clock auction format seems to have been successful in persuading bidders to bid up to their full valuations for the products. This format also enabled bidders to base their demands for each product on the prices of all the products, and the various product groups closed in a quick and orderly succession.

\section{The U.K. Greenhouse Gas Emissions Trading Scheme Auction}

In 2002 the U.K. government initiated a greenhouse gas emissions trading scheme (ETS) intended to facilitate an efficient reduction in greenhouse gas emissions. As part of the introduction of this arrangement, the government offered incentive payments to U.K. companies committing to reduce greenhouse gas emissions. Emission reductions that are paid for from the incentives fund form company emission reduction targets. Companies have the option of meeting their targets by either reducing their emissions or purchasing emission permits from other participants in the ETS. Companies are able to sell or bank emission permits if they reduce their emissions below their targets.

The U.K. government allocated the incentive payments among U.K. companies by auction. In the world's first auction for greenhouse gas reduction, March 11 and 12, 2002, the U.K. government offered incentive payments of $£ 215$ million. The government was advised by Environmental Resources Management, Natsource Tullett Europe, and Market Design. ${ }^{19}$

19. The author, together with University of Maryland professor Peter Cramton, managed Market Design's participation in the project, which included contributing to the design of the auction, developing the auction software, and advising the government in the conduct 
The auction was conducted with a descending price clock, because it was a procurement auction or "reverse auction": the government sought to purchase emission reductions at minimum cost. The auctioneer (buyer) posted a price in pounds per metric ton of carbon dioxide (or the equivalent), and bidders (firms) bid the quantity in metric tons of emission reductions that they were prepared to make at that price. In each new round, the government announced a successively lower price, and bidders indicated the quantity of emission reductions that they were prepared to make at the lower price. Thirty-eight U.K. firms logged onto a website, www.etsauction.com, and participated in the auction. In the first round of bidding, the auctioneer named a price of $£ 100$ per metric ton, and the bidders collectively indicated a willingness to reduce their emissions by 4.9 million metric tons. The price was then allowed to descend until a point was reached where the budgeted $£ 215$ million in incentive monies was exactly spent. This occurred in round nine, at a price of $£ 53.37$ per metric ton. The thirty-four winning bidders collectively took on the obligation to reduce their annual greenhouse gas emissions below their 1998-2000 levels by 4 million metric tons over five years.

While the design of the U.K. ETS auction was quite a bit simpler than that of the EDF auction, three aspects of the design may be especially instructive to the issuance of new equity securities. First, as is typically the case with equity issuance, a single product was auctioned-but in enormous quantities. A clock auction design, where the auctioneer names prices and bidders respond with quantities, is particularly well suited to such circumstances. Indeed, essentially the identical rules and software system from the ETS auction can be used for IPOs, only with the price clock adjusted to ascend rather than descend.

Second, the role of price discovery was particularly important in the U.K. ETS auction; nobody had a clear idea as to the true economywide cost of reducing carbon dioxide and equivalent emissions. In this respect, the ETS auction was very close in spirit to a speculative IPO, where again it is often difficult to predict with any accuracy the closing price after the first day of trading. It is precisely in such a situation of substantial uncertainty

of the auction. Institute for Advanced Studies professor Eric Maskin, Oxford University professor Paul Klemperer, and Stanford University professor Jeremy Bulow also made major contributions to the auction design. More detailed information about the U.K. ETS auction is available at www.efficientauctions.com/co2.htm [May 31, 2002] and www.defra. gov.uk/environment/climatechange/trading/auction.htm [May 31, 2002]. 
regarding value where dynamic auction processes offer the strongest advantages over sealed-bid auctions.

Third, as illustrated by the U.K. ETS auction, dynamic clock auctions may easily accommodate situations where the quantity being auctioned may depend on the market-clearing price. The ETS auction was an extreme case of this: the total quantity of emission reductions transacted equaled a predetermined budget divided by the market-clearing price. Just as easily, an IPO auction may be implemented in which fewer shares are offered at a lower price and more shares are offered at a higher price (or the reverse).

\section{Auction Theory, Continued: The Efficient Ascending Auction}

The auction format described in depth in the previous section, for the EDF and ETS auctions, is a dynamic version of the uniform-price auction. The price is allowed to adjust iteratively until demand equals supply, bidders are allotted the quantities that they bid at the final clearing price, and each bidder's payment equals the final clearing price multiplied by his final quantity. This section of the paper describes an alternative dynamic auction design, sometimes referred to as the "Ausubel auction." It uses the same general structure, but a different payment rule. Theoretically and experimentally, this alternative design yields more efficient allocations than a uniform-price auction, and it may be especially well suited for security issuance. ${ }^{20}$

\section{Illustrative Example}

This efficient ascending-clock procedure is easiest illustrated with an example where five units of identical items are available for auction, although the procedure will work just as easily with 5 million units (for example, shares of stock in an IPO). For simplicity, let us suppose that there are four bidders. Suppose that the auction begins with the auctioneer announcing a price of 10 and suppose that the bidders respond with the following quantities:

20. A more detailed description and results can be found in Ausubel (1997, 2000a, 2000b). 


$$
\frac{\text { Price }}{10} \quad \frac{\text { Bidder A }}{3} \quad \frac{\text { Bidder B }}{2} \quad \frac{\text { Bidder C }}{2} \quad \frac{\text { Bidder D }}{2}
$$

Then, at the initial price of 10 , the aggregate demand of $3+2+2+2=9$ exceeds the available supply of 5 . The price needs to adjust upward; assume that it increases continuously. Now suppose that the bidders continue to bid the same quantities until the price reaches 25 , at which point bidder $\mathrm{D}$ drops out of the auction, yielding:

$$
\frac{\text { Price }}{25} \quad \frac{\text { Bidder A }}{3} \quad \frac{\text { Bidder B }}{2} \quad \frac{\text { Bidder C }}{2} \quad \frac{\text { Bidder D }}{0}
$$

At the price of 25 , the aggregate demand of $3+2+2+0=7$ continues to exceed the available supply of 5 . However, examine this situation carefully from bidder A's perspective. Bidder A's opponents collectively demand only $2+2+0=4$ units, whereas 5 units are available. It may now be said that bidder A has clinched winning 1 unit: whatever happens now (provided that bidders B through D bid monotonically), bidder A is certain to win at least 1 unit. The auction rules take the fact of clinching literally and award a unit to bidder $\mathrm{A}$ at the clinching price of 25 .

Since there is still excess demand, the auctioneer continues to adjust the price upward. Suppose that the next change in bidders' demands occurs at a price of 30, at which point bidder B reduces her demand from 2 to 1 , yielding:

$$
\frac{\text { Price }}{30} \quad \frac{\text { Bidder A }}{3} \quad \frac{\text { Bidder B }}{1} \quad \frac{\text { Bidder C }}{2} \quad \frac{\text { Bidder D }}{0}
$$

At the price of 30 , the aggregate demand of $3+1+2+0=6$ continues to exceed the available supply of 5. However, again, examine this situation carefully from bidder A's perspective. Bidder A's opponents collectively demand only $1+2+0=3$ units, whereas 5 units are available. It may now be said that bidder A has clinched winning 2 units: whatever happens now (provided that bidders B through D bid monotonically), bidder A is certain to win at least 2 units. The auction rules continue to take the fact of clinching literally and award a second unit to bidder $\mathrm{A}$ at the new clinching price of 30. By the same token, let us examine this situation carefully from bidder C's perspective. Bidder C's opponents collectively demand only 
$3+1+0=4$ units, whereas 5 units are available. It may therefore be said that bidder $\mathrm{C}$ has clinched winning 1 unit: whatever happens now (provided that bidders $\mathrm{A}, \mathrm{B}$, and $\mathrm{D}$ bid monotonically), bidder $\mathrm{C}$ is certain to win at least 1 unit. The auction rules take the fact of clinching literally and award a unit to bidder $\mathrm{C}$ at the clinching price of 30 .

Since there is still excess demand, the auctioneer continues to adjust the price upward. Suppose that the final change in bidders' demands occurs at a price of 35 , at which point bidder $\mathrm{B}$ reduces her demand from 1 to 0 , yielding:

$$
\frac{\text { Price }}{35} \quad \frac{\text { Bidder A }}{3} \quad \frac{\text { Bidder B }}{0} \quad \frac{\text { Bidder C }}{2} \quad \frac{\text { Bidder D }}{0}
$$

At the price of 35 , the aggregate demand of $3+0+2+0=5$ is brought equal to the supply of 5 . Thus the market-clearing price is 35 . Bidder A, who had already received a first unit at 25 and a second unit at 30 , wins a third unit at 35. Bidder $\mathrm{C}$, who had already received a first unit at 30 , wins a second unit at 35 . In summary, we have the following auction outcome:

\begin{tabular}{|c|c|c|c|c|}
\hline Outcome & Bidder A & Bidder B & Bidder C & Bidder D \\
\hline & 3 & 0 & 2 & 0 \\
\hline Payments & $25+30+35$ & 0 & $30+35$ & 0 \\
\hline
\end{tabular}

Thus bidders are awarded the quantities that they bid at the final price, but bidders pay according to the prices at which they clinch the various units.

\section{Mathematical Description}

Let $p$ be the price that is posted by the auctioneer and is increased continuously. ${ }^{21}$ Let $n$ be the number of bidders, let $S$ be the supply of items being auctioned, let $x_{i}(p)$ denote the quantity bid by bidder $i$ at price $p$, and let $x_{-i}(p)=\sum_{j \neq i} x_{j}(p)$ denote the aggregate quantity bid by bidder $i$ 's opponents at price $p$. Then the cumulative amount clinched by bidder $i$ at price $p$ is defined by the following equation:

$$
c_{i}(p)=\max \left\{0, S-x_{-i}(p)\right\} .
$$

21. An analogous description would apply to a descending-clock procurement auction (or reverse auction), only now the auctioneer would pay the winning bidders. 
Let $\tilde{p}$ denote the clearing price, that is, $\tilde{p}=\min \left\{p: \sum_{j=1}^{n} x_{j}(p) \leq S\right\}$, and let $p_{0}$ denote the initial price in the auction. Bidder $i$ wins the quantity, $x_{i}(\tilde{p})$, of units bid at the clearing price. The payment of bidder $i$ for these units is given by the following equation:

$$
y_{i}=\int_{p_{0}}^{\tilde{p}} p d c_{i}(p),
$$

where equation 2 is calculated as a Stieltjes integral. This means that, at every point where the value $c_{i}(p)$ increases by one unit, an amount equal to the current value of $p$ is added to the payment (that is, exactly the clinching calculation described informally above).

\section{Results on the Efficient Ascending Auction}

Many conventional auction formats for multiple items have theoretical properties that are less than ideal. In particular, in the sealed-bid uniformprice auction that is now used for the U.S. Treasury auction, optimizing bidders engage in "demand reduction." 22 Bidders have an incentive to bid less than their true valuations, and the incentive to reduce demand increases in the quantity bid. As a result, the sealed-bid uniform-price auction tends to inefficiently allocate the items being sold. With a wellfunctioning secondary market, this inefficient allocation is likely to come at the seller's expense. ${ }^{23}$ Furthermore, this theoretical property of inefficiency is likely to be the same or even worse in dynamic uniform-price auctions. $^{24}$

By contrast, the efficient ascending auction has highly desirable properties. In theory, bidders have every incentive to bid sincerely: that is, to bid exactly their true valuations on every unit for which they bid. With all bidders bidding their true valuations - and with the winners being determined by the high bids - the auction has the attractive property of allotting all items to the bidders who value them the most. The following theorem holds: If bidders have (weakly) diminishing private values, then under complete or incomplete information, sincere bidding by every bidder is an equilibrium of the Ausubel auction. In this equilibrium outcome, the allocation of items is fully efficient. Moreover, in suitable specifications of the

22. Ausubel and Cramton (1996).

23. Ausubel and Cramton (1999).

24. See, for example, Ausubel and Schwartz (1999). 
game, under complete or incomplete information, sincere bidding survives iterated elimination of weakly dominated strategies; and under incomplete information and a "full support" assumption, sincere bidding is the unique outcome of iterated elimination of weakly dominated strategies.

\section{Underpricing of New Issues, Current IPO Practice, and Auctions}

One of the best-established facts of the finance literature on IPOs is the persistent existence of underpricing in the offering price. For example, Ritter reports in his paper in this volume that, among a sample of 6,249 IPOs in the United States from 1980 to 2001, the mean percentage increase from the offering price to the end-of-first-day price equaled 18.8 percent. Most spectacularly, the mean first-day return in 1999 was 71.7 percent, and the mean first-day return in 2000 was 56.1 percent.

By way of comparison, an IPO auction offers the promise of all but eliminating the underpricing. In theory, the clearing price in a welldesigned auction is virtually equal to the market price, so the first-day return should be essentially zero. And, in practice, IPO auctions have tended to yield much smaller underpricing than current practice.

Nevertheless, one observes that the use of auctions for IPOs may have actually declined, worldwide, over the past two decades. Even in countries where the IPO tender was previously well established, auctions have been abandoned in favor of other IPO methods. ${ }^{25}$ For example, in the United Kingdom, fifteen of twenty-four offerings in 1983 were done by tender, whereas no private sector IPOs by tender have occurred there since $1986 .{ }^{26}$ In the United States, W. R. Hambrecht and Company began to conduct IPOs by auction but was only able to find six clients willing to go public in this way.

The puzzle is thus why auctions - inexpensive to run and destined to reduce underpricing - have not gained in the securities area as they have in other sectors of the economy. This paper does not answer this puzzle. However, this section explores the various explanations for underpricing that have been put forth in the literature. It then indicates how modern auction techniques can be used to accomplish the same goals that underpric-

25. Sherman (2001).

26. Jenkinson and Ljungqvist (1996, p. 13). 
ing allegedly serves. So part of the explanation for the trend away from auctions in the securities area may simply be that nobody has tailored modern auction techniques to serve the needs of firms going public.

\section{Explanations in the Literature for IPO Underpricing}

Myriad explanations have been put forth in the literature to explain the empirical regularity of IPO underpricing. My treatment here borrows heavily from that of Jenkinson and Ljungqvist. ${ }^{27}$ Some of the explanations put forth for underpricing include the following:

-The winner's curse. Suppose that some investors are asymmetrically informed about the value of the new stock. Then uninformed investors stand a greater chance of being allocated shares in the IPO when the informed investors' information is unfavorable. Without underpricing, the uninformed investors face a "lemons" problem, and they would not participate in the IPO. With underpricing, the uninformed investors can still earn nonnegative returns in the IPO despite the fact that they receive disproportionate allocations of shares when the informed investors' information is unfavorable.

-Underpricing as a signal. Suppose that the firm has superior information about the value of the new stock and that it is less costly for a highvalue firm than a low-value firm to underprice its shares. Then, as in a classic signaling model, the firm may use underpricing to credibly convince investors that the value of the new stock is high.

- Issuer or underwriter liability. Suppose that issuers, underwriters, accountants, and other parties associated with securities issuance in the United States are preoccupied with potential shareholder lawsuits following an IPO that goes bust. Since the potential liability may be limited to the amount that the share price drops below the offering price, the various parties may have an interest in depressing the offering price (that is, in underpricing).

- Price support. Suppose that underwriters of IPOs take on the obligation of intervening in the aftermarket to help prevent the stock price from falling below the offering price for some number of days after the issue. To the extent that this is the case, the ex post initial-days returns may be a truncated distribution, and so the apparent underpricing may not be a real phenomenon.

27. Jenkinson and Ljungqvist (1996, chs. 3-5). 
-Dispersion of ownership to retain control. Suppose that the managers of a firm have an incentive to disperse the post-IPO ownership among many small investors, in order to exacerbate the separation of ownership and control for the managers' benefit. Then the managers may welcome an arrangement under which the issue is underpriced-and, therefore, radically oversubscribed - so that purchases may be rationed to very small blocks of shares.

- Concentration of ownership to enhance monitoring. Conversely, suppose that the owners of a firm recognize that a large outside investor provides a public good to other investors by monitoring the firm's management. Then the owners may underprice the issue in order to provide extra incentive for an outside investor to acquire a large stake.

- Guaranteed return. Suppose that the owners of a firm are primarily concerned with realizing a given price or amount of money from the IPO and are relatively indifferent about the extent to which this price or amount of money is exceeded. Then the owners may be happy with an arrangement that guarantees them the given price or amount of money, even at the cost of significant underpricing in some states of the world.

-Underpricing as a marketing event. Suppose that the owners (and buyers) of dot.com firms going public in 1997-2000 equated IPO success with a very high first-day return. Then firms may have agreed to vastly underprice their issues in order to obtain the resulting marketing "pop" on capital markets.

\section{Explanations for Underpricing and the Relationship with Auctions}

Some of the pre-Internet-bubble explanations put forth for IPO underpricing make little sense within the context of the 71.7 and 56.1 percent mean first-day returns in 1999 and 2000, respectively. For example, the price support explanation may argue that apparent 5 percent underpricing is spurious, but cannot possibly suggest that 50 percent underpricing is anything but a real phenomenon. Other explanations (such as underpricing as a marketing event) appear to lean heavily on issuer or capital market stupidity and so are difficult to disprove on rational grounds. However, the purpose of this subsection is to explain how many of the effects put forth to justify underpricing can be handled in a superior fashion by a securities auction. In some cases, the instrument being auctioned must be widened beyond simply a share of stock, or the service being provided by the auc- 
tioning intermediary must be widened beyond the simple sale of shares of stock.

-The winner's curse. To the extent that it is present, this structure of asymmetric information may create problems for any method of IPO. However, it is worth reemphasizing that some mechanisms outperform others in the face of the winner's curse. In particular, the accepted wisdom in the auction literature is that dynamic ascending-bid auctions are superior to static sealed-bid auctions with respect to the winner's curse. The intuition for this result is that uninformed bidders in an ascending-bid auction receive continuous feedback about the level of participation of informed bidders, so that when the informed bidders' information is unfavorable, uninformed bidders have greater opportunities to infer this and to respond accordingly.

-Underpricing as a signal. Many commentators have questioned the empirical relevance of the signaling explanation. As Jenkinson and Ljungqvist note, would firms signal through underpricing if they had a wider menu of signals to choose from? ${ }^{28}$ Apart from the more obvious signals, such as a choice of a particularly reputable underwriter or venture capitalist, offerings of longer-term price guarantees can serve as quite effective signals. For example, bundled together with the issued share can be a derivative security that returns $x$ percent of any decline in the share's market price during a one-year period following the IPO. Similar to a quality warranty, this serves as a classic credible signal, since a longerterm price guarantee is relatively less costly for a high-value firm than for a low-value firm. The new shares and the associated derivative securities can be auctioned simultaneously, eliminating much of the cost of underpricing.

- Issuer or underwriter liability. Again, many commentators have questioned the empirical relevance of the liability explanation. Drake and Vetsuypens find that litigation appears to be driven by large declines in the aftermarket price long after the IPO, not by the offering price of the IPO. ${ }^{29}$ Alexander notes that, while damages under the Securities Act of 1933 are limited to declines below the offering price, damages under the Securities Exchange Act of 1934 are not so limited..$^{30}$ In any case, she

28. Jenkinson and Ljungqvist (1996, p. 55).

29. Drake and Vetsuypens (1993).

30. Alexander (1993) further opines, "It is difficult to imagine circumstances in which a 1933 Act claim could be brought but a 1934 Act claim could not be alleged." 
argues, underpricing would be an inefficient and ineffective means for avoiding issuer or underwriter liability. Jenkinson and Ljungqvist conclude that this explanation is a good example of a U.S.-centric model that fails in the international context: severe liability is a U.S. phenomenon, while IPO underpricing is a global phenomenon. ${ }^{31}$

- Price support. It is not necessarily the case that price supports following the IPO should be viewed as value-enhancing or desirable, but if they are, there appear to be much more efficient ways to accomplish this as part of an auction process. One possibility is for the underwriter or auctioneer to provide price support explicitly as part of the services rendered for its fees-as in current practice, this could be provided for, in part, through use of an over-allotment (or "green shoe") provision. A second possibility is to bundle together, with the issued share, a derivative security that returns $x$ percent of any decline in the share's market price during a short period following the IPO—in principle, this percentage could be as high as 100 percent.

-Dispersion of ownership to retain control. If the issuer wishes to disperse the post-IPO ownership among many small investors, this can be easily built into auction rules. For example, it is standard to restrict bidders to no more than $y$ percent of the total supply offered: if the issuer wishes to disperse ownership, $y$ percent can be set at 1 or 2 percent, or some other very low level. Obviously, this dispersion will come at the expense of auction revenues, but the cost should still be much lower than the current cost of underpricing. Furthermore, the dispersion can be locked in for some time, for example by providing a one-for-ten bonus share for investors who retain their shares for more than one year or by providing a one-forten bonus share capped at a limited number of bonus shares per investor.

- Concentration of ownership to enhance monitoring. Again, if the issuer wishes to concentrate the post-IPO ownership among large investors, this can be easily built into auction rules. For example, some of the shares can be offered in a very large lot size (with bidders not permitted to bid on only a fraction of the lot for these shares). It should also be noted that the efficient ascending auction automatically provides some benefits to a bidder who chooses to acquire a large number of shares.

- Guaranteed return. A guaranteed price or amount of money from the IPO is another feature that is easily built into the auction procedure. One

31. Jenkinson and Ljungqvist (1996). 
simple approach is to use a reserve price in the auction. A more complicated approach is for the issuer and the underwriter (or auctioneer) to establish an arrangement in which the underwriter guarantees the issuer a given price or amount of money. In return, the underwriter receives a negotiated percentage of the extent to which the price, or proceeds, exceeds the guaranteed level. In all likelihood, such an arrangement is more beneficial to the issuer than the current underpricing, since the issuer receives the guaranteed amount plus, typically, a positive share of the proceeds above the guaranteed amount.

-Underpricing as a marketing event. In the environment following the Internet bubble and the Credit Suisse First Boston investigation, it seems relatively easy to educate issuers that an oversubscribed auction that rations bidders via a very high market-clearing price provides just as good marketing "pop" in the capital markets as an oversubscribed process that rations bidders via under-the-table commissions paid to the underwriter.

\section{Additional Aspects of Security Issuance by Auction}

This section explores some additional, pragmatic issues concerning the issuance of new securities by auction. The discussion includes how a securities auction might be organized (including who would be the bidders), the regulatory inhibitions to using auctions for securities issuance, and recent attempts to introduce IPO auctions in the United States.

\section{Who Are the Bidders?}

One can easily imagine two alternative, basic structures for an IPO auction: investors as bidders or intermediaries as bidders.

INVESTORS AS BIDDERS. Instead of fixing an offering price and then rationing shares to investors at that price, the underwriter conducts an auction in which investors act as bidders. The offering price is determined so as to set demand equal to supply - that is, price is itself the rationing device. Investors submit bids according to the same considerations they apply in making buy and sell decisions in the aftermarket, and —in principle - the auction clearing price should be approximately equal to the aftermarket price. 
As in current IPO practice, the underwriter and accounting firm perform a due diligence review of the issuer and prepare a prospectus before the auction. The auction itself is conducted as an ascending clock: the auctioneer names a price, and bidders respond with quantities; the auctioneer raises the price, and bidders respond with revised quantities; and the process iterates until demand is brought equal to supply. Bidders win the quantities of shares that they demand at the final price.

One approach is for participation in the ascending-clock auction to be limited to institutional investors. Optionally (and similar to the practice of U.S. Treasury auctions), small investors could be given the opportunity to submit "noncompetitive" bids, which would be honored at the clearing price of the auction. Another approach is for participation in the ascending-clock auction to be open to all bidders-small investors as well as institutional investors. Obviously, investors would need to provide financial guarantees for their bids: for example, bids could effectively be placed through bidders' brokerage accounts, and the same limits could be applied as for ordinary secondary-market purchases of shares.

Some of the desirable characteristics of current IPO practice could be preserved in an auction process by bundling related derivative securities with the offered shares of stock or by modifying the auction rules to restrict purchases in various ways. Moreover, derivative securities could be bundled with the stock shares in new ways to create further value. Here are some examples:

-Each share of stock could be bundled with a call option to purchase an additional 0.15 share of the stock at the clearing price of the auction for a short period of time after the auction, thus replicating standard "green shoe" provisions of IPOs, which tend to stabilize prices (but now effectively requiring bidders to pay for the call option).

-Each share of stock could be bundled with a put option to sell 0.50 share of the stock at the clearing price of the auction for a one-year period after the auction, thus providing a price guarantee that small investors might consider to be valuable (and that would encourage participation by small investors). ${ }^{32}$

32. Such a put option might need to be guaranteed by an escrow account or might be purchased from a well-capitalized third party in order to give credibility to the price guarantee. 
- The quantity demanded by each bidder could be limited to 1 percent of the issuer's total shares in order to encourage a wide dispersion of ownership among investors.

However, there is no particular reason why such derivative securities need to be bundled with shares of stocks in any fixed proportion. Indeed, in all likelihood, some bidders will value price protection more than others and will desire different mixtures of stocks and derivatives. As a result, a superior IPO design is to conduct a multiple-clock auction for two goods: the shares of stocks and the derivative securities. (In practical terms, the EDF auction design, which involved multiple products, could be exploited.) For example, a quantity of 10 million shares of stock, together with a quantity of 5 million put options at the clearing price, are offered simultaneously. Let $\left(p_{\text {share }}, p_{\text {put }}\right)$ denote prices for the two securities and let $\left(q_{\text {share }}, q_{\text {put }}\right)$ denote associated quantities. The auction is conducted with two ascending clocks: the auctioneer names a price vector $\left(p_{\text {share }}^{1}, p_{\text {put }}^{1}\right)$, and bidders respond with quantity vectors $\left(q_{\text {share }}^{1}, q_{\text {put }}^{1}\right)$; the auctioneer raises the prices to $\left(p_{\text {share }}^{2}, p_{\text {put }}^{2}\right)$, and bidders respond with revised quantities $\left(q_{\text {share }}^{2}\right.$, $\left.q_{\text {put }}^{2}\right)$; and the process iterates until demand for both securities is brought equal to supply. Bidders win the quantities of shares and put options that they demand at the final prices.

INTERMEDIARIES AS BIDDERS. As an alternative structure, instead of contracting with a single investment bank to act as lead underwriter, an issuer conducts an auction in which investment banks (or other intermediaries) themselves act as bidders. The investment banks submit bids for shares in the auction knowing that they must earn their profits from the difference between the prices that they pay the issuer in the auction and the prices at which they can resell the shares to investors. Competition within the auction process determines — and, in principle, should limit — the level of profits that investment banks can earn in the IPO.

Under such a structure, in advance of the auction, each investment bank is given an opportunity to examine the issuer's operations and books in detail in order to form its own assessment of the value of shares in the aftermarket. Quite possibly, each investment bank bidding would be responsible for providing its own due diligence services. The auction itself is conducted as an ascending clock: the issuer names a price, and bidders respond with quantities; the issuer raises the price, and bidders respond with revised quantities; and the process iterates until demand is brought 
equal to supply. The investment bank bidders win the quantities of shares that they demand at the final price, and they can dispose of their shares in whatever way they see fit.

Some of the embellishments to the auction described above could also be used here. For example, each share of stock could be bundled with a call option to purchase an additional 0.15 share at the clearing price for a short period of time after the auction, to replicate standard "green shoe" provisions. At the same time, it is less likely that longer-term price guarantees or other arrangements would be offered: these are more likely arrangements that individual investment banks would make with the investors to whom they distribute their shares.

\section{Regulatory Inhibitions}

There appear to be a number of regulatory inhibitions to introducing IPO auctions in the United States, but none of these inhibitions seems insurmountable.

First, the U.S. Securities and Exchange Commission (SEC) heavily regulates the entire IPO process, and so SEC approval would be necessary for any novel procedure. Beginning in the late 1990s, the SEC began to receive inquiries concerning proposed online auction procedures. The SEC staff responded by issuing letters indicating that the SEC would not take action against particular proposed procedures. In July 1999, SEC staff issued a "no-action letter" that allowed Wit Capital to offer securities subject to certain conditions, including that a current preliminary prospectus is made available on the website; that investors provide conditional electronic offers to buy securities prior to effectiveness, and these offers to buy are reconfirmed within forty-eight hours of the date of effectiveness; and that the offer to buy is not binding, and the investor may withdraw the offer for a specified period following effectiveness. Since then, the SEC has also issued no-action letters to W. R. Hambrecht and to Bear Stearns. ${ }^{33}$

A requirement that bids must be nonbinding is detrimental to the introduction of auctions. For an auction to work most effectively, bids need to have real consequences. A regulatory requirement making bids nonbinding can be significantly sidestepped: the investment bank appears to be free to bar an investor who backs out of his bids from receiving allocations

33. Carey (2000). 
in future auctions. In addition, to the extent that derivative securities are used to provide short-time price support, the incentive for a bidder to back out of his bids can be minimized. Nevertheless, regulatory rules that effectively reduce the usual binding nature of bids will inhibit the use of auctions - and it is difficult to see any positive benefit from such rulesso it is hoped that the SEC will change its position over time.

Second, some commentators interpret the NASD rules as requiring uniform pricing. However, this interpretation is not unambiguous. While an attempt to charge one price to one class of investors but a higher price to another class of investors is likely precluded, it is less clear whether auction rules that may result in nonuniform pricing should be viewed as "discriminatory." For example, in the pay-as-bid auction and the Ausubel auction, there is no discrimination among different bidders in the bids that they are allowed to submit or in how the winning bids are selected. It is simply in the nature of things that different bidders are likely to submit different bids, and under the auction rules, these different bids may translate to different prices.

A requirement that prices must be uniform is also detrimental to the introduction of auctions. Various formats that yield nonuniform pricing offer advantages, in efficiency or in revenues, over auction formats with uniform pricing. At the same time, the impediment posed by a requirement for uniform pricing should not be overstated. Both the EDF auction design and the emissions trading scheme auction design would fully comply with any requirement for uniform pricing. And, although in theory they are not ideal auction designs, they still offer potentially very large advantages over current IPO practice.

\section{Recent Attempts to Introduce Auctions to U.S. Issues Markets}

The most conspicuous attempts to introduce IPO auctions into the United States were undertaken by WR Hambrecht and Company beginning in 1999. Through Hambrecht's "OpenIPO" process, bids are typically accepted during a three- to five-week period prior to the effective date of the IPO. With the exception that these bids are not formally binding pursuant to the SEC's "no-action letter," the auction is conducted as a sealedbid, uniform-price auction. Bidders submit bids that effectively comprise demand curves for the stock being offered. After the close of the auction, 
the auctioneer aggregates the bids and determines the clearing price at which demand equals supply. Each bidder wins the quantity demanded at the clearing price and pays the clearing price for each share won.

Unfortunately, Hambrecht's efforts have not met with overwhelming success. Only six IPOs have been auctioned by Hambrecht, the most recent one in May 2001. ${ }^{34}$ Three factors appear to have hampered Hambrecht's efforts: (a) Hambrecht is in the second tier of investment banks and appears to be largely unable to attract the issuers that top-tier investment banks are interested in representing; (b) Hambrecht has used a rather protracted, sealed-bid auction process in which bids are not binding, rather than a short and more effective ascending-bid process; and (c) entry by any auction process would have been difficult in an Internet-bubble environment where success of an IPO was gauged by the first-day "pop."

\section{Conclusions: The Political Economy of Innovations in Market Design}

Why have telecommunications spectrum, energy, and environmental markets adopted innovative auction techniques for high-stakes sales, whereas new equity issues markets have stuck with old, severely flawed designs? One possible answer is that the issuance of new securities is badly suited for dynamic auction procedures. However, such an answer seems implausible. In particular, telecom spectrum appears to present valuation uncertainties as great as those of any high-tech IPO; yet an open, transparent, formal auction procedure has been shown to perform well for telecom spectrum.

A better explanation should take notice of whether a market process already exists, with incumbents earning substantial rents from the existing process, or whether a market is starting from scratch. In the case of communications spectrum, governments had previously given away spectrum licenses, and they introduced auctions in 1994 with no prior history of existing spectrum markets of any significance. In the case of the energy sector, the market moved from heavy regulation to substantial deregula-

34. As of March 2002, Hambrecht's completed IPOs by auction were Ravenswood, $\$ 11,550,000$, April 9, 1999; Salon.com, \$27,300,000, June 22, 1999; Andover.net, $\$ 82,800,000$, December 8, 1999; Nogatech, $\$ 42,000,000$, May 17, 2000; Peet's Coffee \& Tea, \$26,400,000, January 25, 2001; and Briazz, \$16,000,000, May 2, 2001. 
tion, again with little history of existing markets. In the case of carbon dioxide reductions, when a decision was made to conduct an auction, no more than one or two interfirm trades had ever taken place.

In each case where an innovative market design was introduced, there were relatively few self-interested market participants with a stake in preserving the status quo market structure. By contrast, in the arena of new security issuance, there exists a legion of powerful investment banks with an enormous stake in maintaining the profits of the current IPO system. So, despite well-established defects in the current system, the incumbents have staved off alternative mechanisms and, in fact, have consolidated use of the current process.

Will the combination of general interest in reforming the recent IPO abuses and recent successes of new market designs in other sectors finally lead to change in the process for new securities issuance? Only time will tell. 


\section{Discussion}

Christian Leuz pointed out that in Germany's Neuer Markt issuers have a choice between auctioning off their shares or going through a more traditional underwriting process, but that out of the 350 initial public offerings since inception, only one chose to go with an auctioning mechanism. He also noted that since more than thirty lead banks were involved in these initial public offerings, one would assume that competition eventually would whittle down the kickbacks if any were involved. Hence perhaps the incentives of issuers and managements, issuer stupidity, or practical problems with the auction mechanisms could explain this lack of interest in auctions.

Leuz also questioned whether Ausubel's mechanism is coalition- or coercion-proof since the dominant strategy could be clinched by two or more firms acting together. Ausubel responded that if in his mechanism or in any auction procedure bidders were allowed to collude, this would change the incentive properties of the auction and could obviously degrade its performance. Hence any auction procedures he described need to be used in conjunction with good anticollusion mechanisms. A participant added that many institutional investors and individual investors are involved in buying initial public offerings, and hence the collusion of a small number of parties is not a likely scenario.

Reena Aggarwal commented that although academics treat initial public offerings as isolated events, in reality much more complex processes are involved and started before the offering takes place, and they continue with the research analysis, banking relationships for the future, margin advisers, and so on. She added that an isolated view would ignore these other important characteristics. 
David Crosen noted that a standard result of auction theory is that, in order to get bidders to reveal what their true values are, issuers have to leave some information rent on the table. He asked whether Ausubel had calculated how much information rent is actually being left on the table for bidders collectively and how efficient his auction might be compared to other auction mechanisms, in terms of raising money for the issuers rather than allocating it to the right people. He suggested that perhaps IPO issuers do not like auctions since they involve giving a lot of information rent to the people who are contracting for large quantities. Ausubel replied that his theorem assumes private information and that the mechanism is subject to the same incentive constraints on information, hence his results encompass information rents. He added that, in terms of seller revenues, it is not possible to raise any more revenues than is possible from an efficient allocation given that an efficient secondary market follows the auction.

In response to a question about WR Hambrecht auctions, Ausubel stated that there is nothing fundamentally defective about the procedure, although the current wisdom generally prefers ascending-bid auction formats over sealed-bid auction formats. He added, however, that there are problems, such as the fact that all bids are indicative and do not have any binding effect on bidders; he also noted that this might be due to Securities and Exchange Commission rules preventing someone from running an auction where the bidder can be directly held to the bid. He suggested that the Securities and Exchange Commission get rid of any rules or reinterpret those that might have the effect of dooming an auction from working properly.

One participant noted that if a firm with a good reputation does due diligence on the company, there is true value added, and this might explain why auctions should not take place. Ausubel responded that there is no reason why the issuing firm could not hire a reputable investment bank to do due diligence, compensate the bank for its services based on the work done, and then have an auction.

Another participant observed that in an auction large investment banks that would then market the securities, not retail investors, are the bidder. Ausubel responded that he envisions a system somewhere in between, where institutions are bidders as well as retail investors. 


\section{References}

Alexander, Janet C. 1993. "The Lawsuit Avoidance Theory of Why Initial Public Offerings Are Underpriced." UCLA Law Review 41 (October): 17-73.

Ausubel, Lawrence M. 1997. “An Efficient Ascending-Bid Auction for Multiple Objects.” Working Paper 97-06. University of Maryland.

—. 1999. "Computer-Implemented Methods and Apparatus for Auction." U.S. Patent 5,905,975, issued May 18, 1999.

. 2000a."An Efficient Dynamic Auction for Heterogeneous Commodities." Unpublished paper. University of Maryland.

_ 2000b. "System and Method for an Efficient Dynamic Auction for Multiple Objects." U.S. Patent 6,026,383, issued February 15, 2000.

Ausubel, Lawrence M., and Peter Cramton. 1996. "Demand Reduction and Inefficiency in Multi-Unit Auctions." Working Paper 96-07. University of Maryland.

_. 1999. "The Optimality of Being Efficient." Unpublished paper. University of Maryland.

Ausubel, Lawrence M., and Jesse Schwartz. 1999. "The Ascending Auction Paradox." Unpublished paper. University of Maryland.

Bagwell, Laurie S. 1992. "Dutch Auction Repurchases: An Analysis of Shareholder Heterogeneity." Journal of Finance 47 (March): 71-105.

Carey, Paul R. 2000. "Technology, Capital Markets, and the Digital Divide." Speech given by the SEC commissioner, December 6.

Chen, Hsuan-Chi, and Jay R. Ritter. 2000. "The Seven Percent Solution.” Journal of Finance 55 (3): 1105-31.

Cramton, Peter. 1995. "Money Out of Thin Air: The Nationwide Narrowband PCS Auction." Journal of Economics and Management Strategy 4 (2): 267-343.

Drake, Philip D., and Michael R. Vetsuypens. 1993. "IPO Underpricing and Insurance Against Legal Liability." Financial Management 22 (Spring): 64-73.

Economist. 2001. "Wall Street under Scrutiny: A Penny in Whose Pocket?" Economist, May 26-June 1, pp. 71-72.

Gay, Gerald D., Jayant R. Kale, and Thomas H. Noe. 1991. "Share Repurchase Mechanisms: A Comparative Analysis of Efficacy, Shareholder Wealth, and Corporate Control Effects." Financial Management 20 (Spring): 44-59.

Jenkinson, Tim, and Alexander Ljungqvist. 1996. Going Public. Oxford University Press.

Kandel, Shmuel, Oded Sarig, and Avi Wohl. 1999. "The Demand for Stocks: An Analysis of IPO Auctions." Review of Financial Studies 12 (Summer): 227-47.

Labate, John. 2001. "U.S. May Drop IPO Rule Changes: Doubts Are Increasing as to Whether Changing Share Allocation Practice Would End Abuses." Financial Times, December 12, p. 23.

Malvey, Paul F., and Christine M. Archibald. 1998. "Uniform-Price Auctions: Update of the Treasury Experience." Unpublished paper. Department of the Treasury. 
McAfee, R. Preston, and John McMillan. 1987. "Auctions and Bidding." Journal of Economic Literature 25 (2): 699-738.

McGeehan, Patrick. 2001. "First Boston Seen Settling Kickback Case.” New York Times, December 12, p. C1.

Milgrom, Paul. 2000. "Putting Auction Theory to Work: The Simultaneous Ascending Auction." Journal of Political Economy 108 (2): 245-72.

Milgrom, Paul, and Robert Weber. 1982. "A Theory of Auctions and Competitive Bidding." Econometrica 50 (5): 1089-122.

Sherman, Ann E. 2001. "Global Trends in IPO Auctions: Book Building vs. Auctions." Unpublished paper. University of Notre Dame.

U.S. Department of the Treasury, U.S. Securities and Exchange Commission, and Board of Governors of the Federal Reserve System. 1992. Joint Report on the Government Securities Market. Washington: U.S. Government Printing Office, January.

Vickrey, William. 1961. "Counterspeculation, Auctions, and Competitive Sealed Tenders.” Journal of Finance 16 (1): 8-37. 